\title{
HERNIA IN ANCIENT HELLENIC ART. A PARADIGM OF BLENDED COURSES OF ANATOMY AND SURGERY, OR A VOTIVE OFFERING IN THEURGICAL MEDICINE?
}

\author{
Konstantinos LAIOS $^{1}$, Gregory TSOUCALAS ${ }^{2}{ }^{\circledR}$, George ANDROUTSOS ${ }^{3}$, \\ Marianna KARAMANOU ${ }^{1}$ \\ ${ }^{1}$ Department of the History of Medicine and Medical Deontology, University of Crete, Heraklion, Greece \\ ${ }^{2}$ History of Medicine, Anatomy Department, School of Medicine, Democritus University of Thrace, \\ Alexandroupolis, Greece \\ ${ }^{3}$ History of Medicine, The Biomedical Research Foundation of the Academy of Athens, Athens, Greece \\ Received 02 Febr 2019, Accepted 04 March 2019 \\ hitps://doi.org/10.31688/ABMU.2019.54.1.25
}

\begin{abstract}
Hernia was a common problem in Hellenic antiquity as we may infer by a plethora of references in ancient Greek and especially in Byzantine medical literature. However, in ancient Greek art there discovered only two examples representing this rather common surgical entity. Hernia is depicted in two Hellenistic terracotta figurines, one male and one female. They were part of a course in an ancient school or votive offerings in a sacred ancient temple. Although surgery was an existent medical branch at the era, it seems that only a radical ablation, probably fatal, was performed by medico-philosophers and surgeons.
\end{abstract}

Keywords: hernia, ancient Hellenic art, ancient Greek medicine, Smyrna.

\section{RÉSUMÉ}

La hernie dans l'art hellénique antique. Un paradigme de cours d'anatomie et de chirurgie, ou une offrande votive dans la médecine théurgique?

La hernie était un problème courant dans l'antiquité hellénique, comme on peut en saisir de la pléthore de références dans le grec ancien et surtout dans la littérature médicale byzantine. Cependant, dans l'art grec ancien, seuls deux exemples représentaient cette entité chirurgicale. La hernie, est représentée dans deux figurines hellénistiques en terre cuite, un mâle et une femelle. Elles faisaient partie d'un cours dans une ancienne école ou des offrandes votives dans un ancien temple sacré. Bien que la chirurgie soit une branche médicale existante à cette époque, il semble que seule une ablation radicale, probablement fatale, ait été pratiquée par des médecins-philosophes et chirurgiens.

Mots-clés: hernie, art hellénique antique, médecine grecque antique, Smyrna. 


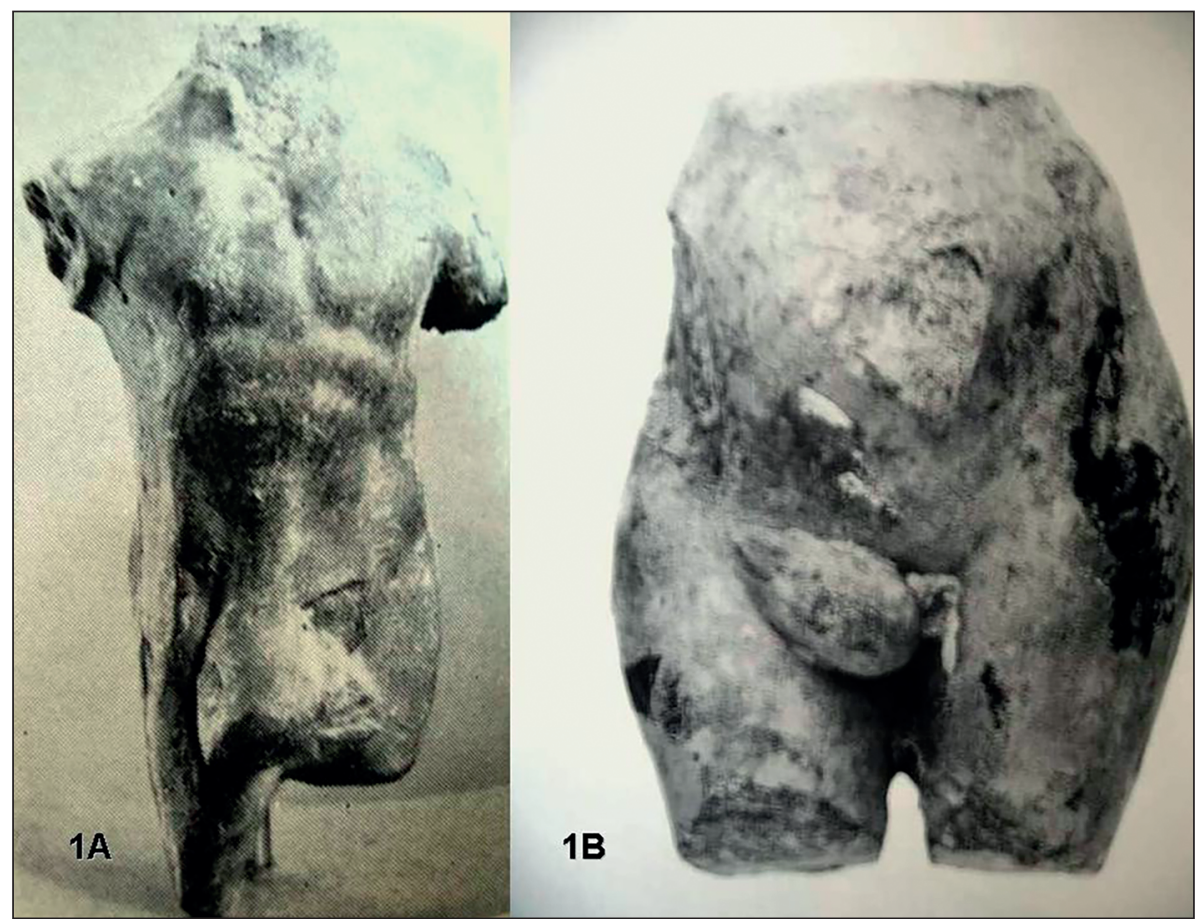

Fig. 1. A. Male terracotta figurine, Paris, Louvre Museum, D 1206. B: Female terracotta figurine, Jena, Friedrich-Schiller-Universitä, Institut für Geschichte der Medizin, Naturwissenschaft und Technik, Ernst-Haeckel-Haus, V 27.

A series of medical ancient Greek writers referred to hernia as a common problem among other surgical entities. Both Galen (Galenus Med. De tumoribus praeter naturam 7.730.8-11) ${ }^{1}$ and Paul of Aegina (Paulus Med. Epitomae medicae libri septem 3.53.1.1-3.53.2.13) $)^{2}$ described it, while in ancient Greek art two figurines actually depicted it. Surgery was more advanced as it is widely believed, and various abdominal surgical operations were performed by surgeons in ancient Greece. However, no description or any other evidence suggests that hernias were operated under a reconstructive procedure. A radical excision of the mass, with most probably fatal results, seems to have been the general concept ${ }^{3-4}$. During the Hellenic antiquity, the usage of terracotta figurines for teaching purposes in philosophical-medical schools was in vogue. The tilers of the era should have molded terracotta figurines which represented shaped depictions of lethal and rare diseases for every apprentice to visualize them ${ }^{5-6}$.

Two Hellenistic terracotta figurines, a male and a female one, preserved in a fragmentary condition depicted an inguinal hernia. Their torso and a part of their thigh survived depicting this surgical condition. Both represent nude figures with a prominent bulge in their right inguinal area, allowing us to conclude that this is a depiction of hernia. The male figurine was unearthed in Smyrna (Fig. 1A) ${ }^{7-8}$, while the female is a part of the Meyer-Steineg Collection with no other information as it was collected through an iniquitous antiquity trade (Fig. 1B) .

The case of the male figurine depicts a hernia with greater volume, probably idolizing an inguinoscrotal hernia. We may hypothesize that this figure was used as a model during a propaedeutic educational program of the famous ancient medical school of Smyrna. The same concept seems to be valid for a series of other terracotta figurines found in the same territory by archaeologists ${ }^{10}$. On the other hand, the characteristics of the female case of a hernia, propose as an icon more a femoral than an inguinal hernia. Although it may be one more example of an educational model, some researchers believe that it was probably used as a votive limb ${ }^{11}$.

It looks like that anatomical malformations were always an important part of the physicians' training, while blended courses which promote excellence ${ }^{12}$, existed among the best schools since the era of the ancient Greeks. However, those figurines may have been used for the purposes of the theurgical medicine as votive offerings in sacred temples for a miraculous cure to be begged ${ }^{13-14}$, as a surgical intervention was not really an option during that era. Whichever may have been their usage, the fact of the presence of such pathological enlargements attracted the minds of both the medico-philosophers and the common people. 


\section{Compliance with Ethics Requirements:}

„The authors declare no conflict of interest regarding this article"

\section{References}

1. Galen. De tumoribus praeter naturam, ed. J. Reedy, Galen. De tumoribus praeter naturam. Michigan. Dissertation University of Michigan. 1968:1-28.

2. Paul. Epitomae medicae libri septem, ed. J.L. Heiberg, Paulus Aegineta, 2 vols. [Corpus medicorum Graecorum, vols. 9.1 \& 9.2. Leipzig, Teubner, 1921-1924: 9.1:3-388; 9.2:5-411. (Cod: 206,400: Med.).

3. Tsoucalas G, Sgantzos M, Androutsos G. Hippocrates, Principles on Abdominal Surgery in Ancient Greece During the Fifth Century bc. Surg Innov. 2016;23(2):212-213.

4. Tsoucalas G, Markatos K, Karamanou M. The Hippocratic method of surgical cauterization for the tumescence spleen in the rare "Spetses Syndrome". Surg Innov. 2018;25(4):413-416.

5. Pournaropoulos GK. The teaching of medicine in Greece. Asclepius 1930(4);10: 1082-1083.

6. Laios K, Karamanou M, Tsoucalas G, Sgantzos M, Androutsos G. Ophthalmic malignancies in antiquity as depicted in two terracotta figurines. J BUON 2015;20(2):650-2.
7. Besques S. Musée national du Louvre. Catalogue raisonné des figurines et reliefs en terre-Cuite grecs, étrusques et romains. Epoques hellénistique et romaine, Grèce et Asie mineure, III. Paris, Éditions des Musées nationaux, 1971-1972.

8. Stevenson WE. The pathological grotesque Representation in Greek and Roman art. Pennsylvania, Dissertation University of Pennsylvania, 1975.

9. Forsén B. Griechische Gliederweihungen: eine Untersuchung zu ihrer Typologie und ihrer religions- und sozialgeschichtlichen Bedeutung. Helsinki, Suomen Ateenan-instituutin säätiö, 1996.

10. Laumonier A. Terres-cuites d'Asie Mineure. BCH 1946;70:312-318.

11. Künzl E, Zimmerman S. Notizien zu den votiven der sammlung Meyer-Steineg in Jena Teill II. JbRGZM 1994; 41(1):179-198.

12. Tsoucalas G. Anatomy: An Essential Course for Future Surgeons. Journal of Universal Surgery. 2018;6(1):8.

13. Tsoucalas G, Karamanou M, Laios K, Sgantzos M, Androutsos G. The Forgotten Asclepieion of Peparithos and the Islander Worshippers of the Snake God. J Relig Health. 2016;55(1):43-49.

14. Laios K, Tsoucalas G, Karamanou M, Androutsos G. The medical-religious practice of votive offerings and the representation of a unique pathognomonic one inside the Asclepieion of Corinth. J Relig Health. 2015;54(2):449-454. 